\title{
Integrated decision support system for acoustic diagnostics in the technical state of the internal combustion engine
}

\author{
Zintegrowany system wspomagania decyzji do diagnostyki \\ akustycznej w badaniu stanu technicznego silnika spalinowego
}

ADAM DEPTUKA

PIOTR OSIŃSKI *

DOI: https://doi.org/10.17814/mechanik.2017.7.77

\begin{abstract}
Presented are possible applications of acoustic diagnostics in inspecting the technical condition of an internal combustion engine with autoignition on the example of the Fiat drive unit with common rail system. As a result of measuring the sound pressure level for specific faults and comparing the noise generated by the motor running smoothly, the detailed maps of changes in the acoustic spectrum are possible to generate. These results may be helpful in the future diagnostics of internal combustion engines. The results of scientific work in the area of research, design and operation of internal combustion engines, conducted at the Department of Automotive Engineering, in cooperation with the Laboratory of Hydraulic Drives \& Vibroacoustics of Machines at the Wroclaw University of Technology are included. It has developed an authoritative method of identifying the type of engine damage using game-tree structures. An integrated decision system for induction machine learning was developed to test and identify acoustic properties.

KEYWORDS: game-tree structures, acoustic diagnostics, combustion engine, induction of decision trees
\end{abstract}

Safety and economic requirements force machine users to minimize unplanned repairs and breakdowns. One of the elements of rational use of machines is their regeneration. On the basis of diagnostic observation you can plan the date and possible range of regenerative procedures, as well as prepare the materials and subassemblies for replacement. One of the main problems of diesel engine designers is the design of a reliable on-board diagnostics (OBD) system - self diagnostics of cars. Such systems are also the reason for increasing the overall dimensions and production and operating costs of internal combustion engines.

\footnotetext{
* Dr inż. Adam Deptuła (a.deptula@po.edu.pl) - Instytut Innowacyjności Procesów i Produktów, Wydział Inżynierii Produkcji i Logistyki Politechniki Opolskiej; dr hab. inż. Piotr Osiński (piotr.osinski@pwr.edu.pl) - Katedra Eksploatacji Systemów Logistycznych, Systemów Transportowych i Układów Hydraulicznych, Wydział Mechaniczny Politechniki Wrocławskie
}

The mandatory function of these systems is to measure and monitor the basic parameters of the propulsion system, including all emission parameters. It is important to develop a system for measuring acoustic wave spectrum that eliminates background noise and other components that do not affect engine performance [1].

Investigating the engine operating parameters is important both in the production process, as well as during operation. The measurements, it is possible to diagnose associated with malfunction of the engine or other parameters deviating from the desired, e.g. consumption [2, 3]. In [4, 5], authors focus on the study of the reliability of acoustic diagnostics engine Fiat 1.3 JTD 70 bhp. The measurements consisted of comparing the sound pressure level of specific engine operating frequencies with induced faults with the smooth running of the engine. In addition, the publication [5] has created a decision system based on graphs and parametric play structures that identify the damage based on the spectral characteristics of the sound emission. Expanding the decision-making tool by creating a hybrid integrated system will allow future development of a diagnostic method for non-invasive control of the engine's technical condition.

\section{Study of internal combustion engine}

Measurements are presented in papers [4, 5]. They refer to the common rail diesel engine - Fiat 1.3 JTD series 188A9000. A total of 13 acoustic waveform studies were conducted for the various faults of the examined engine. The B \& K Type 2250 Series Volume Meter with Time History and Frequency Analysis (sonometer, class I accuracy) was used to determine the $L_{e q A}$ average sound level (in $\mathrm{dB}$ ), the maximum $L_{\text {Amax }}$ (in $\mathrm{dB})$ and the minimum $L_{A m i n}(\mathrm{~dB}) 2506429$ with preamplifier type ZC 0032 factory no. 4112 and microphone type 4189 no. 2519832 . Before starting and after measurements, the entire measuring circuit was calibrated. A standard sound pressure source with a strictly defined level of $L_{p}=93.98 \mathrm{~dB}$ was used. Compliance is confirmed by the current calibration certificate of the District Office of Measures in Wroclaw No. W5/401-156/1/12 of 17 July 2012. The test bench consisted of a eddy current brake comprising a cooling system, a current winding and a polar disc mounted on a shaft which is connected the crankshaft of the engine. The sound level meter was placed at a distance $d=1 \mathrm{~m}$ of a parallelepiped which surrounds the motor housing, designated in accordance with accepted norm [4, 5]. 


\section{Measurement results}

The first study was the measurement of the background noise on the test bench. The noise is primarily caused by the flow of the cooling liquid system of the eddy current brake. Another 12 measurements were performed for the six different cases state diagnostic engine with a load of $80 \mathrm{Nm}$, two engine speeds $-1000 \mathrm{rev} / \mathrm{min}$ and $2000 \mathrm{rev} / \mathrm{min}$. The time of each measurement was $t=10 \mathrm{~s}$. These included the following cases $[4,5]$ :

- engine in perfect diagnostic condition not warmed,

- engine in perfect diagnostic condition after the proper operating temperature is reached,

- sensor of exhaust gas recirculation EGR disconnected,

- boost pressure sensor disconnected,

- position sensor camshaft disconnected,

- injector \#2 disconnected.

The results were obtained in the form of sound pressure applied to a particular frequency graphs for [4, 5]. The differences in sound pressure level relative to the reference level calculated by the formula:

$$
\Delta L=10 \log \left(\left|10^{0,1 L_{n}-0,1 L_{0}}\right|\right)
$$

where: $\Delta L$ - change in the sound pressure in $\mathrm{dB} ; L_{0}-$ reference sound pressure (motor without fault) in $\mathrm{dB} ; L_{n}$ - sound pressure value for the $n$-th sample in $\mathrm{dB}$.

\section{Integrated decision support system}

Integrated decision systems are based primarily on representing experts' knowledge through: rules if, then so-called frames to describe the object; fuzzy logic rules; semantic web and a description of cases. These systems use a largely artificial intelligence methods. It plays an important role knowledge base, which is an extension of the database and is built for each system separately. System knowledge bases are written in the language of the knowledge base description, integrating the declarative language of knowledge representation, and the imperative language of structural programming.

Papers [4, 5] discuss the use of expert sound diagnostic system to support the field implementation process. Often, the set of analyzed data (learning examples) is written to the first order logic. The mapping functions examples of a suitable set of terms may be requested a number of methods (among others [7]). One method of classification of information and decision support is inductive generating rules using decision trees $[8,9]$.

\section{Classification using induction trees}

In the generation of inductive decision trees, a series of tests is carried out in a specific order, and the criterion for choosing the attribute for the expansion of the tree is entropy. In the classification with the use of induction trees it is assumed that the domain $X$ is given, where the attributes $a_{1}, a_{2}, \ldots, a_{n}$ are defined, the notion class $C$ of the category $C$ and:

- a leaf containing any category label $d \in C$ is a decision tree;
- $t: X \rightarrow R_{t}$ is a test performed on the values of attributes of examples with a set of possible results $R_{t}=\left\{r_{1}, r_{2}, \ldots\right.$ $\left.r_{m}\right\}$.

Each of the finite number of possible outcomes of the test corresponds to the branch leading from the node to the sub-tree. If a node contains a test $t$ with a result set $R_{t}=\left\{r_{1}, r_{2}, \ldots r_{m}\right\}$, and the corresponding branches lead to sub-trees $T_{1}, T_{2}, \ldots T_{m}$, then the hypothesis represented by this node can be given for each example $x \in X$ written as follows:

$$
h(x)=\left\{\begin{array}{l}
h_{1}(x) \text { jeśli } t(x)=r_{1} \\
h_{2}(x) \text { jeśli } t(x)=r_{2} \\
\cdots \\
h_{m}(x) \text { jeśli } t(x)=r_{m}
\end{array}\right.
$$

where: $h_{1}, h_{2}, \ldots h_{m}$ are hypotheses respectively represented by the trees $T_{1}, T_{2}, \ldots T_{m}$.

Expected value of information after division of the set of examples $E$ into subsets $E^{(m)}, m=1, \ldots,\left|V_{a}\right|$, for which the attribute a has the value $V_{m}$, is defined as $[8,9]$ :

$$
I(E, a)=\sum_{m=1, K,\left|V_{a}\right| E^{(m)}=\varnothing} \frac{\left|E^{(m)}\right|}{|E|} \cdot I\left(E^{(m)}\right)
$$

where: $\left|E^{(m)}\right|$ - number of examples after division of the set $E$ by the value of $m$ of the attribute; $|E|$ - number of examples in the learning set $E$.

\section{Application of induction decision trees in the diagnosis of technical condition}

For the set of examples, a collection of learning and testing examples should be built. This requires the input (in) and output (out) attributes. For the purpose of creating a learning file, the decision parameters were: $X_{1}$ - disconnected pressure sensor, $X_{2}$ - disconnected shaft position sensor, $X_{3}$ - disconnected injector No. $2, X_{4}-$ disconnected fuel sensor - for $L_{e q A}$ in $\mathrm{dB}$ for 1000 and $2000 \mathrm{rpm}$ and attributes:

- input (in) of the frequency: $f=\{6,3 \mathrm{~Hz}$ (in), $8 \mathrm{~Hz}$ (in), 10 $\mathrm{Hz}$ (in), $12,5 \mathrm{~Hz}$ (in), ..., $20 \mathrm{kHz}$ (in), $A($ in), Z (in)\};

- output (out) of the accepted defects for $L_{m A}$ in $\mathrm{dB}$ for $1000 \mathrm{rpm}: X_{\mathrm{n}}^{(1000)}=\left\{X_{1}^{(1000)}(\right.$ out $), X_{2}^{(1000)}$ (out), $X_{3}^{(1000)}$ (out), $\left.X_{4}^{(1000)}(o u t)\right\}$;

- output (out) of the accepted defects for $L_{m A}$ in $\mathrm{dB}$ for 2000 rpm: $X_{n}^{(2000)}=\left\{X_{1}^{(2000)}(\right.$ out $), X_{2}^{(2000)}$ (out), $X_{3}^{(3000)}$ (out), $X_{4}^{(4000)}$ (out)\}.

The following knowledge database lines contain the $L_{\text {eqA }}$ results in $\mathrm{dB}$ as examples. In learning file *.Irn, learning examples are written, while test files *.tst write test examples for validating classifications. Taking into account the additional graphing tool [4, 5], a more integrated decision system can be achieved. The classification process acoustic data can be presented on the basis of a general scheme (figure). 


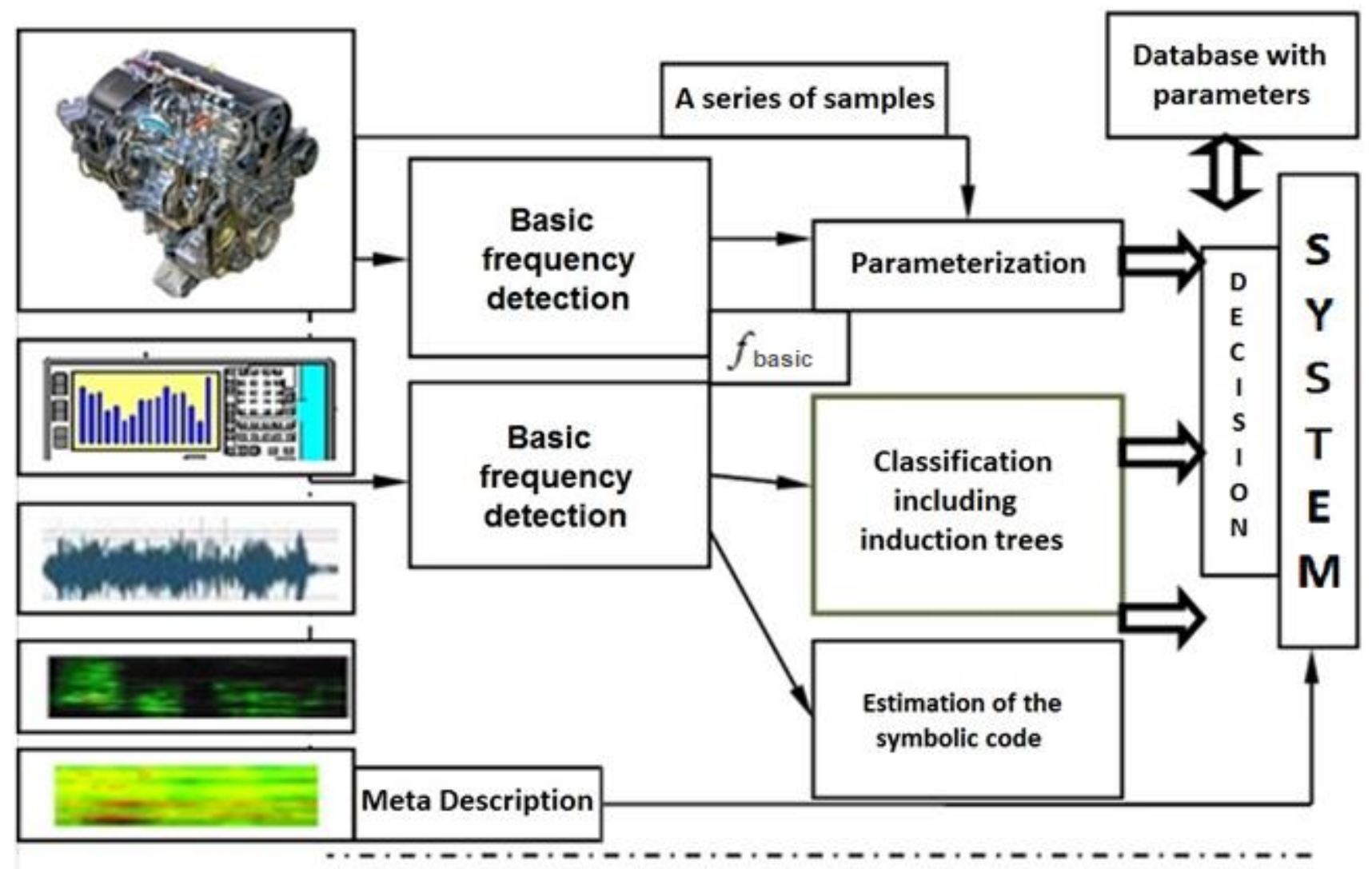

Fig. Example query to the decision system query by example.

\section{Conclusions}

As a result of the measurement of sound pressure level read for specific faults and comparison with the noise generated by the engine running smoothly, it is possible to generate accurate maps of changes in the sound spectrum. In this method, the diagnosis should pay attention to the characteristic changes of the sound spectrum for specific faults:

- disconnected boost pressure sensor - the main changes apply to $315 \mathrm{~Hz}$ and $2.5 \mathrm{kHz}$ because there is a clear drop in sound pressure at both $1000 \mathrm{rpm}$ and $2000 \mathrm{rpm}$. These differences are approximately -1.5 $\mathrm{dB}$ at $315 \mathrm{~Hz}$ at both rotational speeds and $-1.01 \mathrm{~dB}$ at $1000 \mathrm{rpm}$ and $-0.66 \mathrm{~dB}$ at $2000 \mathrm{rpm}$ for $2.5 \mathrm{kHz}$;

- disconnected camshaft position sensor - the best image of the spectral change is generated during the test at a rotational speed of $1000 \mathrm{rpm}$. At higher revolutions there were no significant differences;

- disconnected injector no. 2 - the only type of fault that can be detected with an unarmed ear; strong increase in low- and mid-frequency noise;

- disconnected fuel pressure sensor - a situation similar to that of a disengaged camshaft position sensor, with the exception of both gain and damping waves are smaller.

In works [4, 5], the graph of the parametric search algorithm found characteristics, characteristic points or values (individual for each failure), with which one could pre-characterize the damage to which the sound pressure distribution should be analyzed. Induction decision trees allow you to build a measuring ladder that will determine the type of engine damage based on sound pressure measurements on selected frequencies.

\section{REFERENCES}

1. Zhen D., Wang T., Gu F., Tesfa B., Ball A. "Acoustic measurements fort the combustion diagnosis of diesel engine fuelled with biodiesels". Meas. Sci. Technol. 24 (2013): 055005.

2. Osiński P., Kollek W. "Assessment of energetistic measuring techniques and their application to diagnosis of acoustic condition of hydraulic machinery and equipment". Archives of Civil and Mechanical Engineering. 13, 3 (2013): pages 313-321.

3. Adaileh W.M. "Engine fault diagnosis using acoustic signals". Applied Mechanics and Materials. 295-298 (2013): pages 20132020.

4. Deptuła A., Kunderman D., Osiński P., Radziwanowska U., Włostowski R. "Acoustic diagnostics applications in the study of technical condition of combustion engine". Archives of Acoustics. 41, 2 (2016): pages 345-350.

5. Deptuła A., Osiński P., Radziwanowska R. "Decision support system for identifying technical condition of combustion engine". Archives of Acoustics. 41, 3 (2016): pages 449-460.

6. Pieczyński A. "Reprezentacja wiedzy $w$ diagnostycznym systemie ekspertowym". Zielona Góra: Lubuskie Towarzystwo Naukowe w Zielonej Górze, 2003.

7. Merthold M., Hand D. "Intelligent data analysis. An introduction". Berlin: Springer Verlag, 1999.

8. Quinlan J.R. "Induction of decision trees". Machine Learning. 1 (1986): pages 81-10.

9. Deptuła A. „Indukcyjne drzewa decyzyjne (entropia) jako odpowiednik zmodyfikowanych drzew logicznych w wyznaczaniu rangi ważności zmiennych decyzyjnych projektowanego układu". XLIII Konf. Zast. Mat. Zakopane 2014. Warszawa: Inst. Mat. PAN. 